\title{
Effect of Soil Type and Forage Crops on Manganese Content in Roughage
}

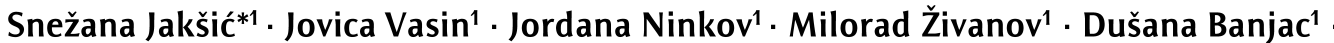 \\ Nada Grahovac ${ }^{1}$. Gordana Dozet ${ }^{2}$
}

${ }^{1}$ Institute of Field and Vegetable Crops, Maksima Gorkog 30, 21000 Novi Sad, Serbia

2"John Naisbitt" University, Faculty of Biofarming, Maršala Tita 39, 24300 Bačka Topola, Serbia

\begin{abstract}
Summary: The aim of this study was to examine the effects of soil type and forage crops on the content of manganese $(\mathrm{Mn})$ in roughages, and forage quality regarding $\mathrm{Mn}$ content. The trial was carried out on chernozem and humogley under alfalfa and red clover. Samples for determination of Mn content in plant and total Mn content in soil were digested using the apparatus Milestone Ethos 1 and for Mn determination on ICP-OES Vista Pro-Axial Varian. Average total Mn content in soil of the tested sites was $473.1 \mathrm{mg} / \mathrm{kg}$. Total Mn content in chernozem was higher than in humogley. Average Mn content in forage crops was $28.7 \mathrm{mg} / \mathrm{kg}$. Dry matter Mn content was lower in crops grown on humogley. Mn content was significantly higher in red clover. Significant positive correlation was found between total $\mathrm{Mn}$ content in soil and Mn content in crops. Mn concentration in crops was below critical and toxic value.

Key words: alfalfa, chernozem, humogley, manganese, red clover
\end{abstract}

\section{Introduction}

In plants, manganese $(\mathrm{Mn})$ plays a key role in many oxidation-reduction processes, activation of enzymes, photosynthesis, metabolism of carbohydrates and lipids, and synthesis of plant pigments. It is especially important for the fixation of atmospheric nitrogen $(\mathrm{N})$ and its metabolism. Manganese negatively affects the uptake of $\mathrm{N}, \mathrm{P}, \mathrm{K}$, and $\mathrm{Ca}$, but does not negatively affect the yields because it increases the costeffectiveness of utilization (Ubavić \& Bogdanović, 1995). Manganese deficiency may result in excessive accumulation of nitrites and nitrates. Lack of Mn often occurs in sandy soils, but more often in soil there is $\mathrm{Mn}$ excess, which may mitigate the presence of alkali and alkaline earth metals (Nable et al., 1984). Excess Mn often occurs in very acid and poorly drained soils.

Manganese originates from ferromagnesium rocks and magmatic rocks silicates, where it is found in minerals. In soil, it can also be found in sparingly soluble salts (tertiary phosphate $\mathrm{Mn}_{3}(\mathrm{PO})_{4} \bullet 7 \mathrm{H}_{2} \mathrm{O}$,

Corresponding author:

snezana.jaksic@ifvens.ns.ac.rs

Acknowledgement:

This study was partially carried out within the project TR31072 "State, tendencies and possibilities of increasing agricultural soil fertility in Vojvodina", financed by the Ministry of Education, Science and Technological Development of the Republic of Serbia.
$\mathrm{MnCO}_{3}$ and $\mathrm{Mn}(\mathrm{OH})_{2}$, organic compounds, adsorbed $\mathrm{Mn}$, and in soil solution (Džamić \& Stevanović, 2000).

Different manganese compounds are found in soil, because $\mathrm{Mn}$ can change its valence. Share of these compounds varies, because it depends on $\mathrm{pH}$ and redox potential (Vasin et al., 2004), which are directly connected to moisture content, aeration, and microbiological activity. Manganese reduction and oxidation are affected by the aforementioned factors, so it can be found in soil in easily and hardly reducible form, which in turn affects its availability to plants. Two -valent $\mathrm{Mn}$ is important for plant nutrition, while sixand seven-valent forms are strong oxidants and are rarely found in soil.

Total Mn content in soil ranges between $200 \mathrm{mg} / \mathrm{kg}$ and $2000 \mathrm{mg} / \mathrm{kg}$ (Kastori, 1990), and it decreases with depth. In soils of Serbia this value ranges from $490 \mathrm{mg} /$ $\mathrm{kg}$ in calcareous chernozem, $670 \mathrm{mg} / \mathrm{kg}$ in smonitza, $650 \mathrm{mg} / \mathrm{kg}$ in brown forest soil, to $800 \mathrm{mg} / \mathrm{kg}$ in pseudogley (Džamić \& Stevanović, 2000).

Since cultivated forage crops show very low $\mathrm{Mn}$ content on many soils, it is important to focus on their $\mathrm{Mn}$ nutrition because of important role of $\mathrm{Mn}$ in animal organisms regarding metabolism of carbohydrates and lipids (Ubavić et al., 2008). Insufficient Mn intake in animals results in abiotic fertility impediments, bone deformations, joint inflammation, and tendency towards corpulence (Ubavić et al., 2008). Manganese excess causes disruptions in Fe metabolism and haemoglobin biosynthesis (Kastori, 1990). 
Alfalfa (Medicago sativa L.) is a perennial legume considered the leading and most important forage crops for quality feed production, which can be used fresh or conserved as hay, haylage, silage, flour, pellets, and paste (Jakšić et al., 2013). Alfalfa favours neutral soils.

Red clover (Trifolium pratense L.) is the second most important perennial forage legume in Serbia. Unlike alfalfa, red clover favours acid soils in mountain areas. Red clover is used for feed as green forage, for grazing (as a single crop or mixed with grasses), and conserved as hay, silage or dehydrated as flour (Jakšić et al., 2013).

The aim of this study was to show the effects of soil type and forage crop on manganese content in roughage, and quality of feed regarding Mn content, because of important role of $\mathrm{Mn}$ in animal nutrition.

\section{Materials and Methods}

The trial was set up on calcareous chernozem in Novi Sad (GPS 44²0'00.8"N 1949'58.6"E) and

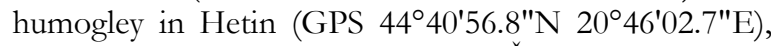
both in Serbia, classified as such by Škorić et al. (1985). Alfalfa and red clover were grown on both locations on seven field plots (repletions).

Soil and plant material were sampled in May 2011, which was the second production year of alfalfa and red clover. Soil samples were collected in disturbed state using agricultural probe from two depths $(0-30 \mathrm{~cm}$ and $30-60 \mathrm{~cm})$. One composite soil sample consisted of 1525 individual samples. The collected samples were airdried and grinded to particle size $<2 \mathrm{~mm}$ according to SRPS/ISO 11464:2004.

Plant material samples for chemical analyses were collected directly after harvest from the clippings (second cutting, May). Fodder was manually harvested at the beginning of flowering, and crops were cut at 5 $\mathrm{cm}$. Plant material samples were air-dried and milled.

Samples for determination of Mn content in plant material and total $\mathrm{Mn}$ content in soil were digested in closed microwave system under high pressure with gradual heating to $180{ }^{\circ} \mathrm{C}$ using the apparatus Milestone
Ethos 1. Samples were digested with concentrated $\mathrm{HNO}_{3}$ and $\mathrm{H}_{2} \mathrm{O}_{2}\left(5 \mathrm{HNO}_{3}: 1 \mathrm{H}_{2} \mathrm{O}_{2}\right)$. Ratio between sample and solvent was 1:12 for soil samples, and 1:24 for plant material samples. Mn concentration was determined in destroyed sample matrix on ICP-OES Vista Pro-Axial Varian.

Humus content in soil was determined according to Tjurin method. Calcium-carbonate content in soil was determined by volumetric method according to ISO 10693:1995. Soil $\mathrm{pH}$ was determined by potentiometric method according to ISO 10390:2005. Content of the tested elements was calculated to air-dry sample.

Study data were processed by the methods of descriptive statistics. Significance of differences between treatments was tested by analysis of variance (ANOVA), and relationships between variables were determined by correlation-regression analysis. Significance of differences was tested by Fisher's LSD test. Data were statistically processed by using Statistica 12.6 (StatSoft, Inc. Corporation, Tulsa, OK, USA).

\section{Results and Discussion}

Chernozem belongs to automorphic soils, the class of humus-accumulating soils, with the profile composition Amo-AC-C. It is developed in semi-arid steppes, on calcareous clayey substrate, rarely on sandy loose substrate (Miljković, 1996). It is dark brown in colour, with a prominent grainy structure and characteristic krotovinas and pseudomycelia. Carbonates occur on surface or in transitional horizon. Basic chemical properties of the tested sites soil are shown in Table 1. According to $\mathrm{pH}$ determined in suspension with $1 \mathrm{M} \mathrm{KCl}$, the chernozem soil belongs to the class of neutral and slightly alkaline soils. Content of $\mathrm{CaCO}_{3}$ greatly varied, rendering the site soils from slightly calcareous to highly strongly calcareous. According to humus content, these soils are weakly humic to humic. In the study of chernozem in Srem region of Serbia, Dozet (2010) reported on $0-17.7 \% \mathrm{CaCO}_{3}$ content, $1.36-5.18 \%$ humus content, and 5.61-7.49 $\mathrm{pH}$.

Table 1. Basic soil chemical properties on the tested sites

\begin{tabular}{|c|c|c|c|c|c|}
\hline Soil type & Depth $(\mathrm{cm})$ & $\mathrm{pH}$ in $\mathrm{KCl}$ & $\mathrm{pH}$ in $\mathrm{H}_{2} \mathrm{O}$ & $\mathrm{CaCO}_{3}(\%)$ & Humus (\%) \\
\hline \multirow{2}{*}{ Chernozem } & $\begin{array}{c}0-30 \\
(\min -\max ) \\
(\bar{x} \pm \mathrm{sd})\end{array}$ & $\begin{array}{c}6.92-7.69 \\
(7.38 \pm 0.24)\end{array}$ & $\begin{array}{c}7.66-8.31 \\
(8.11 \pm 0.18)\end{array}$ & $\begin{array}{r}0.34-16.42 \\
(5.47 \pm 0.34)\end{array}$ & $\begin{array}{c}2.19-3.40 \\
(2.81 \pm 0.44)\end{array}$ \\
\hline & $\begin{array}{c}30-60 \\
(\min -\max ) \\
(\bar{x} \pm \mathrm{sd})\end{array}$ & $\begin{array}{c}6.94-7.80 \\
(7.57 \pm 0.21)\end{array}$ & $\begin{array}{c}7.74-8.41 \\
(8.23 \pm 0.16)\end{array}$ & $\begin{array}{c}0.17-29.90 \\
(13.29 \pm 9.26)\end{array}$ & $\begin{array}{c}1.15-2.85 \\
(2.15 \pm 0.50)\end{array}$ \\
\hline \multirow{2}{*}{ Humogley } & $\begin{array}{c}0-30 \\
(\min -\max ) \\
(\bar{x} \pm \mathrm{sd})\end{array}$ & $\begin{array}{c}5.16-7.35 \\
(6.43 \pm 0.74)\end{array}$ & $\begin{array}{c}6.22-8.15 \\
(7.30 \pm 0.67)\end{array}$ & $\begin{array}{c}0.08-4.21 \\
(0.91 \pm 1.24)\end{array}$ & $\begin{array}{c}3.07-4.93 \\
(3.59 \pm 0.45)\end{array}$ \\
\hline & $\begin{array}{c}30-60 \\
(\min -\max ) \\
(\bar{x} \pm \mathrm{sd})\end{array}$ & $\begin{array}{c}5.76-7.69 \\
(7.20 \pm 0.60)\end{array}$ & $\begin{array}{c}6.94-8.39 \\
(8.04 \pm 0.47)\end{array}$ & $\begin{array}{c}0.08-37.50 \\
(11.42 \pm 11.70)\end{array}$ & $\begin{array}{c}1.23-3.65 \\
(2.08 \pm 0.78)\end{array}$ \\
\hline
\end{tabular}


Table 2. Total Mn content in chernozem and humogley soil of the tested sites under alfalfa and red clover (mg/kg)

\begin{tabular}{|c|c|c|c|c|}
\hline \multirow{2}{*}{ Soil type } & \multirow{2}{*}{ Depth $(\mathrm{cm})$} & \multicolumn{2}{|c|}{ Forage crop } & \multirow{2}{*}{ Average } \\
\hline & & Alfalfa & Red clover & \\
\hline \multirow{3}{*}{ Chernozem } & $0-30$ & 602.2 & 685.0 & 643.6 \\
\hline & $30-60$ & 494.4 & 687.1 & 590.7 \\
\hline & Average & $548.3 b$ & $686.0 c$ & $617.2 a$ \\
\hline \multirow{3}{*}{ Humogley } & $0-30$ & 192.6 & 265.5 & 229.1 \\
\hline & $30-60$ & 439.3 & 418.3 & 428.8 \\
\hline & Average & $316.0 a$ & $341.9 \mathrm{a}$ & $328.9 b$ \\
\hline \multirow{2}{*}{ Average } & $0-30$ & 397.4 & 475.2 & $436.3 \mathrm{a}$ \\
\hline & $30-60$ & 466.9 & 552.7 & $509.8 \mathrm{~b}$ \\
\hline Average & & $432.1 A$ & $514.0 B$ & 473.1 \\
\hline
\end{tabular}

$A$-capital, bold, italic letters- differences between alfalfa and red clover; a-small, bold letters- differences between the depth; $\boldsymbol{a}$ - small, bold, italic letters- differences between soil types; a-small letters- differences between crops at different soil types

-Fisher's test at the level 0.05

Humogley belongs to hydromorphic, gley soils with the profile composition Amo, A -Gso. Mollic horizon is deeper than $50 \mathrm{~cm}$, with the signs of hydromorphism. Parent substrate was made up of various sediments transported by rivers, so it can form on fluviatile deposits, mostly of heavy mechanical composition, redeposited loess and aeolian sand. Regarding soil $\mathrm{pH}$, the tested humogley sites belong to acid, weakly acid, neutral, and weakly alkaline soils. According to $\mathrm{CaCO}_{3}$ content, soils are slightly to strongly calcareous. According to humus content, the site soils are weakly humic to humic. In their study of humogley in Banat region of Serbia (which includes our site Hetin), Belić et al. (2011) also recorded wide range of $\mathrm{CaCO}_{3}$ content $(0$ $-38.3 \%$ ), while humus content ranged between 1.5\% and $5.23 \%$, and $\mathrm{pH}$ between 5.57 and 8.75 .

Average total $\mathrm{Mn}$ content in soil of the tested sites was $473.1 \mathrm{mg} / \mathrm{kg}$ (Table 2). According to other studies, Mn content in Serbian soils ranged from $490 \mathrm{mg} / \mathrm{kg}$ in calcareous chernozem, $670 \mathrm{mg} / \mathrm{kg}$ in smonitza, 650 $\mathrm{mg} / \mathrm{kg}$ in black forest soil, to $800 \mathrm{mg} / \mathrm{kg}$ in pseudogley (Džamić \& Stevanović, 2000). Radanović et al. (2003) reported on average total $\mathrm{Mn}$ content in chernozem to be $590.06 \mathrm{mg} / \mathrm{kg}$. There were significant differences in total Mn content between chernozem and humogley. Total Mn content was higher for $288.3 \mathrm{mg} / \mathrm{kg}$ in

Table 3. Mn content in alfalfa and red clover dry matter $(\mathrm{mg} / \mathrm{kg})$

\begin{tabular}{|c|c|c|c|c|}
\hline & & Alfalfa & Red clover & Average \\
\hline \multirow[t]{7}{*}{ Chernozem } & Site 1 & 33.9 & 31.2 & \multirow{7}{*}{$34,1 \mathrm{a}$} \\
\hline & Site 2 & 33.2 & 35.9 & \\
\hline & Site 3 & 32.8 & 45.1 & \\
\hline & Site 4 & 40.3 & 37.8 & \\
\hline & Site 5 & 26.4 & 33.1 & \\
\hline & Site 6 & 26.2 & 34.8 & \\
\hline & Site 7 & 42.4 & 24.6 & \\
\hline \multicolumn{2}{|c|}{ Average for chernozem } & $33.6 a$ & $34.6 b$ & \\
\hline \multirow[t]{7}{*}{ Humogley } & Site 1 & 12.8 & 36.4 & \multirow{7}{*}{$23,4 \mathrm{~b}$} \\
\hline & Site 2 & 15.9 & 44.0 & \\
\hline & Site 3 & 10.9 & 29.3 & \\
\hline & Site 4 & 16.3 & 25.9 & \\
\hline & Site 5 & 13.8 & 24.6 & \\
\hline & Site 6 & 23.0 & 21.3 & \\
\hline & Site 7 & 15.1 & 37.8 & \\
\hline \multicolumn{2}{|c|}{ Average for humogley } & $15,4 b$ & $31.3 b$ & \\
\hline \multicolumn{2}{|c|}{ Average for both soil types } & $24,5 A$ & $33.0 \mathrm{~B}$ & 28.7 \\
\hline
\end{tabular}

$A$-capital, bold, italic letters- differences between crops; a-small, bold letters- differences between soil types; $\boldsymbol{a}$ - small, bold, italic lettersdifferences between crops at different soil types

-Fisher's test at the level 0.05 


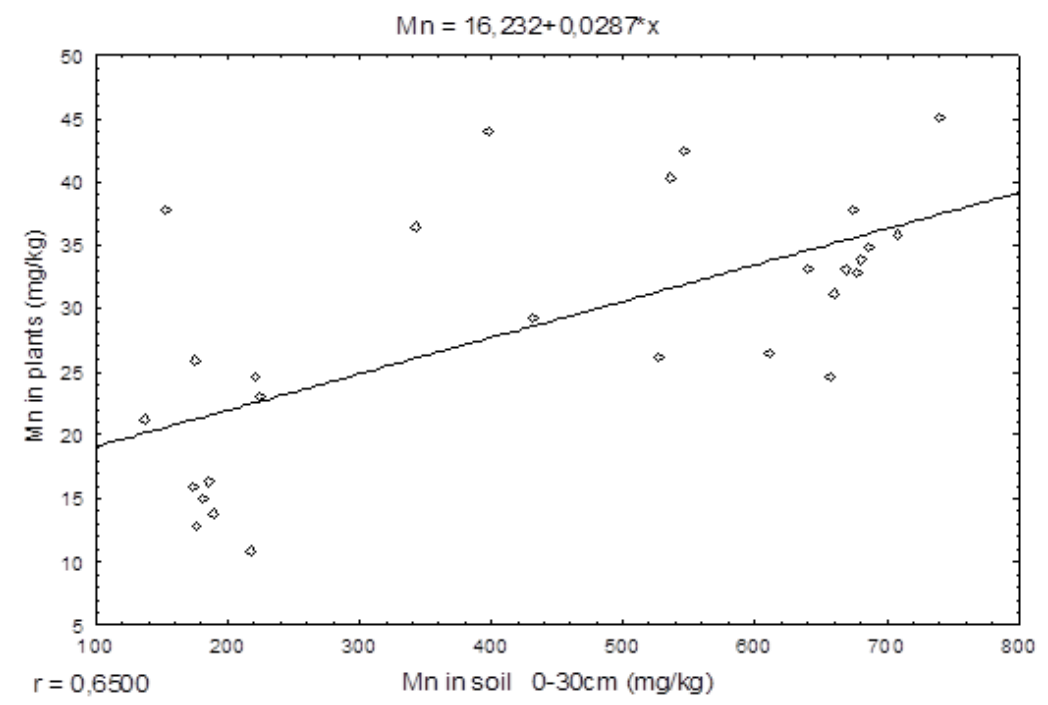

Figure 1. Dependence of Mn content in forage crops dry matter $(\mathrm{mg} / \mathrm{kg})$ on the total Mn content in soil horizon $0-30 \mathrm{~cm}(\mathrm{mg} / \mathrm{kg}), \mathrm{p}<0.05$

chernozem compared to humogley. There were also significant differences between total $\mathrm{Mn}$ content in topsoil and deeper soil horizons. Lower total Mn content in chernozem was in the deeper horizon (30-60 $\mathrm{cm}$ ), which is in agreement with other studies (Kastori, 1990; Ubavić et al., 2008), and it decreases in the horizon deeper than $60 \mathrm{~cm}$ (Gašić et al., 1967, cit. Ubavić \& Bogdanović, 1995). On the other hand, humogley had higher Mn content in the deeper soil horizon.

Significantly higher total Mn content in soil was recorded under red clover in chernozem (by $137.7 \mathrm{mg}$ / $\mathrm{kg})$, than in soil under alfalfa.

Average Mn content in the tested forage crops was $28.7 \mathrm{mg} / \mathrm{kg}$ (Table 3). Limit value for good supply of $\mathrm{Mn}$ is $25 \mathrm{mg} / \mathrm{kg}$ in crop dry matter (Ubavić et al., 2008). Other studies showed that Mn content ranged between 25 and $250 \mathrm{mg} / \mathrm{kg}$, which primarily depends on the crop species, cultivar, crop age, redox-potential, and soil $\mathrm{pH}$ (Kastori, 1990; Ubavić et al., 2008). The samples of alfalfa grown on humogley had Mn content below the limit value for good supply.

Critical concentration of $\mathrm{Mn}$ in crops which can negatively affect life processes in crops and the production of plant mass is $150.0 \mathrm{mg} / \mathrm{kg}$, and toxic concentration is $400.0 \mathrm{mg} / \mathrm{kg}$ dry matter (Kastori et al., 1997). The results of the tested samples were below such concentration limits.

The effect of soil type on Mn concentration in forage crops was highly significant. Manganese content in crop dry matter was lower on humogley than on chernozem, on average by $10.7 \mathrm{mg} / \mathrm{kg}$.

Previous studies indicate that contents of total and available $\mathrm{Mn}$ were in significant positive correlation (Vasin et al., 2011) that resulted in higher uptake of Mn by crops grown on chernozem, which is better supplied with this element and also has lighter mechanical composition. Significant positive correlation $(\mathrm{r}=+0.65)$ was found between total $\mathrm{Mn}$ content in soil depth 0 $30 \mathrm{~cm}$ and its content in the crops (Figure 1).

Red clover average Mn content was higher by 8.5 $\mathrm{mg} / \mathrm{kg}$ than alfalfa average $\mathrm{Mn}$ content, which is a statistically significant difference. The results are in agreement with other studies. Vučković (2004) found Mn content in red clover to range from $24.9 \mathrm{mg} / \mathrm{kg}$ to $120.8 \mathrm{mg} / \mathrm{kg}$, and Lukić (2000) found Mn content in alfalfa to range from $25 \mathrm{mg} / \mathrm{kg}$ to $200 \mathrm{mg} / \mathrm{kg}$. Džamić \& Stevanović (2000) reported lower Mn content in fullbloom alfalfa (42 mg/kg) than in red clover (49 mg/kg). Ignjatović et al. (2001) stated that red clover in bloom contained $45.4 \mathrm{mg} / \mathrm{kg}$ manganese. Szabó et al. (1987) found higher Mn content in red clover than in alfalfa on all tested soil types (loess soils, salt marshes, sandy and andesitic soils), except for waterlogged soils where $\mathrm{Mn}$ content in alfalfa was higher. In their study of chemical composition of alfalfa sampled from 12 different sites in Vojvodina region of Serbia, Živkov-Baloš et al. (2011) found Mn content of $23.5 \mathrm{mg} / \mathrm{kg}$. Marković et al. (2007) reported Mn content in alfalfa on alluvial soil to be $39.4 \mathrm{mg} / \mathrm{kg}$ and in red clover $76.4 \mathrm{mg} / \mathrm{kg}$.

\section{Conclusion}

Average total Mn content in soil of the tested sites was $473.1 \mathrm{mg} / \mathrm{kg}$. Total Mn content in chernozem soil was higher than in humogley soil. Average Mn content in the tested forage crops was $28.7 \mathrm{mg} / \mathrm{kg}$. The effect of soil type on Mn concentration in forage crops was highly significant. Dry matter Mn content was lower in crops grown on humogley than in crops grown on 
chernozem. Significant positive correlation was found between total $\mathrm{Mn}$ content in soil and Mn content in crops. Mn content was significantly higher in red clover than in alfalfa. Samples collected from crops were well provided with $\mathrm{Mn}$, except for alfalfa samples from humogley which had lower Mn content in dry matter. Mn concentration in crops was below critical and toxic value and could not affect negatively organic matter production of the tested crops could decrease organic matter production.

\section{References}

Belić, M., Nešić, L., Ćirić, V., Vasin, J., Milošev, D., \& Šeremešić, S. (2011). Characteristics and classification of gleyic soils of Banat. Ratarstvo i pourtarstvo, 48(2), 375-382.

Dozet, D. (2010). Sadř̌aj nikla u zemlizstima Srema. Master Thesis. Novi Sad: University of Novi Sad, Faculty of Agriculture.

Džamić, R., Stevanović, D. (2000). Agrohemija. Beograd: Partenon.

Ignjatović, S., Vučetić, J., Lugić, Z., \& Dinić, B. (2001). Uticaj faze razvića na sadržaj makro i mikroelemenata u crvenoj i beloj detelini. Agricultural Science Research Journal, 62 (220), 309-316.

International Organization for Standardization (2005). ISO 10390: 2005. Soil quality - Determination of $p H$. Geneve: International Organization for Standardization.

International Organization for Standardization (1995). ISO 10693:1995. Soil quality - Determination of carbonate content Volumetric method. Geneve: International Organization for Standardization.

Jakšić, S. P., Vučković, S. M., Vasiljević, S., Grahovac, N., Popović, V., Šunjka, D. B., \& Dozet, G. K. (2013). Akumulacija teških metala u Medicago sativa L. i Trifolium pratense L. na kontaminiranom fluvisolu. Hemijska industrija, 67(1), 95-101.

Kastori, R. (1990). Neophodni mikroelementi. Beograd: IDP.

Kastori, R. (1997). Teškei metali u životnoj sredini. Novi Sad: University of Novi Sad, Faculty of Agriculture.
Lukić, D. (2000). Lucerka. Novi Sad: Naučni institut za ratarstvo i povrtarstvo.

Marković, J., Ignjatović, S., Radović, J., \& Lugić, Z. (2007). Uticaj faze razvića na sadržaj makro i mikroelemenata u lucerki i crvenoj detelini. Zbornike radova Instituta za ratarstvo i pourtarstvo, 44(1), 401406.

Miljković N. (1996). Osnovi pedologije. Novi Sad: University of Novi Sad, Faculty of Sciences.

Nable, R. O., Bar-Akiva, A., \& Loneragan, J. F. (1984). Functional manganese requirement and its use as a critical value for diagnosis of manganese deficiency in subterranean clover (Trifolium subterraneum L. cv S. Park). Annals of Botany, 54, 39-49.

Radanović, D., Nešić, L. M., Sekulić, P. Đ., Belić, M., Pucarević, M., \& Čuvardić, M. S. (2003). Karakterizacija zemljišta za proizvodnju kvalitetnog lekovitog bilja. Lekovite sirovine, 23, 51-57.

Szabó, S., A., Regiusne, M., Á., Györi, D. \& Szentmihályi, S. (1987). Mikroelemek a mezögazdaságban I. (Esszunciális mikeroelemek). Budapest: Mezögazdasági Kiadó.

Škorić, A., Filipovski, G., \& Ćirić, M. (1985). Klasifikacija zemliista Jugoslavije (vol. 78). Sarajevo: Akademija nauka i umjetnosti Bosne i Hercegovine.

Ubavić, M., Marković, M., \& Oljača, R. (2008). Mikroelementi i mikrodubriva i njibova primena u praksi. Banja Luka: University of Banja Luka, Faculty of Agriculture.

Ubavić, M., \& Bogdanović, D. (1995). Agrohemija. Novi Sad: University of Novi Sad, Faculty of Agriculture.

Vasin, J., Sekulić, P., Kicošev, V., Ninkov, J., Zeremski-Škorić, T., Milić, S., \& Grahovac, N. (2011). Ispitivanje kvaliteta zemlisista u blizini potencijalne ekoloske mreže na prostoru Srednjeg Banata. Novi Sad: Institut za ratarstvo i povrtarstvo.

Vasin, J., Sekulić, P. Đ., Hadžić, V. B., Bogdanović, D., \& Pucarević, M. (2004). Stepen zagađenja nepoljoprivrednog zemljišta u Vojvodini. Zbornik radova Instituta za ratarstvo i povrtarstvo, 40, 129140.

Vučković, S. (2004). Travnjaci. Belgrade: University of Belgrade, Faculty of Agriculture.

Živkov-Baloš, M., Mihaljev, Ž., \& Ćupić, Ž. (2011). Content of trace elements and some radionuclides in lucerne (Medicago sativa L.). Biotechnology in Animal Husbandry, 27(3), 591-598.

\section{Uticaj tipa zemljišta i krmnog useva na sadržaj mangana u kabastoj stočnoj hrani}

\section{Snežana Jakšić · Jovica Vasin · Jordana Ninkov · Milorad Živanov · Dušana Banjac · Nada Grahovac · Gordana Dozet}

Sažetak: Cilj rada je da prikaže uticaj tipa zemljišta i krmnog useva na sadržaj mangana u kabastoj stočnoj hrani, kao i kvalitet krmiva sa aspekta obezbeđenosti manganom. Ispitivanja su izvedena na černozemu i humogleju, na kojima je zasnovana proizvodnja lucerke i crvene deteline. Za određivanje sadržaja Mn u biljkama, kao i ukupnog sadržaja u zemljištu primenjena je digestija uzoraka na aparatu Milestone Ethos 1 i determinacija na ICP-OES Vista Pro-Axial Varian. Prosečan ukupan sadržaj Mn u zemljištu iznosio je 473,1 mg/kg. Ukupan sadržaj Mn u černozmu je bio viši u odnosu na humoglej. Prosečna vrednost sadržaja Mn u ispitivanim biljkama iznosila je $28,74 \mathrm{mg} / \mathrm{kg}$. Niži sadržaj Mn u suvoj materiji biljaka je konstatovan na humogleju. Crvena detelina je imala značajno veći sadržaj Mn. Konstatovana je značajna pozitivna korelaciona veza između ukupnog sadržaja Mn u zemljištu i njegovog sadržaja u biljkama. Koncentracija Mn u biljkama je ispod kritične i toksične vrednosti.

Ključne reči: crvena detelina, černozem, humoglej, lucerka, mangan 